\title{
Réquiem para María Elena: Notas sobre el imaginario de los últimos pampinos ${ }^{1}$
}

Juan Carlos Rodríguez T. ${ }^{2}$, Pablo Miranda B. ${ }^{3}$ y Pedro Mege R. ${ }^{4}$

\section{RESUMEN}

Este artículo refiere a la fuerza y la pervivencia de un imaginario de la pampa y de la cultura del salitre que se resiste a morir, pero que no encuentra referente en María Elena, el último pueblo salitrero. Tal imaginario, como acto compensatorio frente a la desestructuración de la comunidad y su identidad y que se refugia en elementos que no son sincrónicos en el actual espacio físico, laboral, psicológico, social, cultural y político del pueblo y sus habitantes, puede atrapar a antropólogos acostumbrados al yo testifical. Esta compensación es causada por un proceso constante de innovación y eficiencia tecnológica en el siglo XX y por la incorporación de nuevos actores no comunitarios. Se plantea la existencia de relatos cruzados que sobrepasan la propia experiencia de vida, tal vez quedando de este imaginario únicamente el concepto pampino de una estoica lucha por afianzar un territorio que ya no existe y que se sostiene en fragmentos de memoria, los que poco a poco se convierten en un simulacro.

Palabras claves: imaginario - memoria - tradición - simulacro.

\begin{abstract}
This article refers to the long lasting and strong Pampa (desertic land) and Salitre (Nitrate of soda potash) culture imaginary that resists to die, but finds no referent in Maria Elena, the last salitre town. Based on a compensation to the destruction of the community and its identity structure this imaginary traps anthropologists used to the testimonial style. Such compensatory phenomenon is caused by both the constant process of renewal and technological efficiency of the XX century, and the incorporation of actors who do not belong to the community. Thus, the Pampal Salitre imaginary stays in elements that no longer coexist with the physical, industrial, psychological, social, cultural and political reality of the town and its inhabitants. We propose the existence of crossed-stories that surpass daily life. The trompe l'oeil nature of the imaginary experience indicates that it is now only a pampino concept of the stoic fight to preserve a land that no longer exists. Based on fragments of memory, the shredded imaginary slowly turns into a simulacrum.
\end{abstract}

Key words: imaginary-memory - tradition - simulacrum.

Recibido: mayo 2004. Aceptado: mayo 2005.

1 Este trabajo es producto del Proyecto FONDECYT 1010325: "Memoria e imaginación en María Elena, el últi-

\section{La escena de la escritura}

\begin{abstract}
"El dado de la vida nunca cae como se espera. $Y$ a los hombres les rige, mala o buenamente, un rey con los ojos llenos de lágrimas; pero, que se ríe con una monumental boca de payaso. Dicen que es el destino" (Andrés Sabella, Norte Grande).
\end{abstract}

"Empamparse" es volver una y otra vez a este mismo lugar: la pampa. Es no poder huir de ella, enredarse en sus intrincadas historias, caminos y trabajos; deambular con la estirpe rota, con mucho de historias y nostalgias sureñas, y el presente que arremete por todos lados, cuestión que en el pasado fue sinónimo de errar de una oficina a otra, de quedarse a vivir bajo el sol a pesar de extrañar otras tierras y paisajes, de no poder salir. Por eso, Hipólito Pizarro, el caminante extraviado en medio de la nada, en ese lugar en el que todo parece igual, y que vuelve sobre sus propias huellas después de caminar 10 horas inútilmente, y ante la eminencia de la muerte, decide derribar el poste telefónico con el que torpemente tropieza y cortar las comunicaciones como única posibilidad de conexión con el mundo para que alguien llegara a rescatarlo. Cumplido su objetivo, cuando es absuelto por el tribunal -al cual había sido conducido y clamado inocencia-, es interrogado por un periodista quien pregunta: “¿qué vas a hacer? ¿a dónde vas a ir?”, y al que le da una sola respuesta: “¿y a ónde hey d'ir, patrón? a la pampa" (Silva 1938: 36). La respuesta es obvia. Pasado el tiempo, desadaptado de otros

mo pueblo salitrero de Chile. Una visión desde la antropología".

2 Facultad de Educación de la Universidad de Playa Ancha. Casilla 34-V, Valparaíso, V Región, CHILE. Email: juancarlosrodriguezt@yahoo.com

3 Facultad de Arte de la Pontificia Universidad Católica de Chile. Campus Oriente, Av. Jaime Guzmán Errázuriz 3300, Providencia, Santiago, CHILE. Email: pmirandb@puc.cl

4 Escuela de Antropología de la Universidad Academia de Humanismo Cristiano. Condell 343, Providencia, Santiago, CHILE. Email: pmege@academia.cl 
territorios, rotos los lazos con la familia, la pampa es lo único que se tiene, y es desde donde no se puede huir.

Esa imagen del "empampado" se corresponde a lo acontecido durante generaciones en el Desierto de Atacama: los hombres, las mujeres y las familias se quedaron, enterraron a sus deudos, vieron construir las oficinas, el fin de las faenas, apagar las chimeneas y desmantelar la infraestructura, y testifica cómo circularon los hombres de un lugar a otro, girando sobre la misma actividad minera, buscando refugio del sol y del frío, trabajo y alimento. Además, se refuerza esta idea de la recurrencia laboral, de cierta circularidad de la vida, con la construcción de los últimos asentamientos salitreros de Chacabuco (1924), María Elena (1926) y Pedro de Valdivia (1930), los que corresponden a un diseño urbanístico dispuesto a satisfacer todas las necesidades de la población en términos de infraestructura y con los que se da inicio a la construcción de la "vivienda obrera" en Chile (Garcés 1999). Con ello se perfilaría una política sistemática de la empresa Anglo Lautaro para que la población se estabilizara y sus trabajadores se fueran quedando, identificándose con los espacios institucionales que la empresa abría y recreándolos hasta configurar un microcosmos que también es fuente particular de identidad y distinción.

En este sentido, tomando como referencia el detallado estudio urbanístico y de la vivienda de María Elena y Pedro de Valdivia realizado por Garcés (1999), y contrastándolo con las vistas generales de los espacios habitacionales de las oficinas Reducto y San José, ofrecidas en el álbum de las Salitreras de Tarapacá de Luis Boudat (1889 [2001]), puede observarse el cambio significativo en las condiciones de vida de los trabajadores a fines del siglo XIX, y de las primeras décadas del siglo XX. La cuestión no será menor en la perspectiva antropológica, ya que ahí, inevitablemente, se forjará un mundo desconocido hasta antes de finales de los años 20 del siglo pasado, pues estos asentamientos marcan un hito cultural del cambio en la historia de la industria del salitre: condicionan y marcan el nacimiento de los pueblos salitreros.

Leticia Acuña, precoz y eximia pianista, cuya vida transcurrió de la mano de las coyunturas económicas de la industria entre el puerto de Antofagasta y las oficinas Pinto, Coya Sur y María Elena, cuan- do mira la pampa desde esta última, señala con relación a los asentamientos construidos con anterioridad a la década del 20:

“... la gente salía en la noche a la pampa. Usted veía un desfile de gente en la noche; hombres y mujeres, todos a la pampa a hacer sus necesidades ahí... Había que ir a traer agua y ponerla en unos barriles, y para que el agua no se echara a perder se le ponía un pedazo de carbón, un carbón de piedra, para que no criara unos gusanitos que criaba el agua. Uno tomaba de esa agua que estaba tapada con una tabla...". 5

Pedro Araya, peluquero, enganchado desde Ovalle, sin poder desprenderse de una imagen superlativa de la vida vivida en la pampa, señala: "Aquí [en Pedro de Valdivia y en María Elena] aprendimos a ser personas... muchos venían de pueblos donde no había nada... ni luz eléctrica ni agua potable. Aquí fue como una escuela, todos partimos de cero".

Desde otra perspectiva, y de modo general, esta construcción espacio temporal se plasma tempranamente en un habla particular, con préstamos lingüísticos del quechua, del inglés y el español, con onomatopeyas y analogías entre los animales domésticos y la tecnología, que versa sobre la invención de la vida en el desierto y la apropiación de la misma por varias generaciones (Lehnert 1997); es decir, el desierto, como paisaje, marcó los límites de la razón, la emoción, los anhelos de justicia, la vida y la muerte, y las posibilidades de ser de todos aquellos que abrieron fronteras y se movieron por los caminos de la explotación de nitrato. En su esplendor, fueron más de 300 las oficinas salitreras en operación, y unas 120000 personas las que habitaron la pampa.

Sabemos, además, que en la vida del salitre se acrisola el movimiento social y los tempranos movimientos de protesta. Sin embargo, González (2002) señala con ajustada razón, que cuando se marca el énfasis exclusivamente en el trabajo de baja calificación al que accedió gran parte de estos aventureros y pioneros, el término "obrero" se vuelve una categoría estrecha y exógena para caracterizar al trabajador, europea y extraña en esta aventura épi-

\footnotetext{
5 Registro realizado por Patricio Medina $\mathrm{H}$.
} 
ca, que aunque siendo utilizada permanentemente por la historiografía, peca de la falta de un elemento definidor de esta identidad: el paisaje. Sí, se es obrero, pero pampino. Y no es concebible tal condición si no se apela a lo que define su vida: la pampa. Esto es una cuestión vital, en la medida que no hay lugar en el planeta que reconociese las magnitudes de reservas de nitrato y llegase a los niveles de explotación como los conocidos en la explanada del Desierto de Atacama; pero además, es un paisaje de características únicas por su originaria inhabitabilidad, lo que da al hecho de subsistir en él características épicas. A pesar de esto último, miles de almas llegaron en los vapores o en ferrocarril bajo la clásica modalidad del "enganche"6, y en definitiva, dieron forma a un tipo de sociabilidad que con el paso del tiempo da forma a un modo de ser y vivir. ${ }^{7}$

Este proceso expansivo de la explotación del nitrato y de formación de las relaciones sociales capitalistas de producción alcanza su máxima expresión a comienzos de los años 30, y por cierto, por las características de las formas de reclutamiento de trabajadores, no se encuentra exento de dificultades de convivencia intercultural, ya que nunca todos los llegados tuvieron el mismo estatus. De modo hubo importantes y tempranas discusiones sobre la presencia de los chinos en la industria salitrera. Estos llegaban a los puertos en deplorables condiciones desde las zonas agrícolas peruanas que habían sufrido una declinación en su explotación, como también de las guaneras que habían sufrido el mismo proceso; hacían sus travesías en las cubiertas de los vapores, hacinados y mal alimentados, pero siempre fueron considerados una solución importante ante la dificultad de conseguir trabajadores y mano de obra barata y eficiente ${ }^{8}$, lo que alentó la protesta social, ya que su presencia haría disminuir los salarios de los trabajadores chilenos.

6 "Enganche" correspondía a una forma de reclutamiento de trabajadores, en la cual se les ofrecía un contrato, pero con falsas promesas sobre las condiciones de trabajo y de vida que obtendrían con éste.

7 Se estima que en Iquique, territorio peruano, entre 1849 y 1874 habrían llegado cerca de 100000 chinos, los que hacían una travesía de unos 120 días de duración, durante la cual un tercio de ellos moría.

8 Aún después de la anexión de Antofagasta a Chile.
Emblemático resulta ser la concepción que de ellos se tenía entre los trabajadores locales. Se sostenía en el periódico El Pueblo Obrero, de Iquique, del 4 de junio de 1907: "La raza amarilla sería un factor de decadencia al mezclarse con el pueblo chileno" (cit. en Recabarren 2002). Respecto de la presencia de bolivianos, los que también fueron significativos en número, muchos empresarios publicitaron sus necesidades de trabajadores en lengua aymara, a los que, como una forma de atraerlos, se les aseguraba que no les iba a faltar la coca (Recabarren 2002).

En el caso de María Elena, la gente aún recuerda a las familias bolivianas. Blanca Rosa, nos señala estirando su dedo índice: "en esas corridas de casas vivían los bolivianos... cuando uno pasaba por ahí siempre se escuchaban voces. Decían que enterraban a las guaguas debajo del piso, a uno le daba miedo cuando niño". 9

Leticia, los recuerda desde las correrías infantiles:

"Nosotros desde niños, desde muy niños teníamos un antiboliviano y antiperuano tremendo. En los juegos, el insulto que teníamos a los que perdían (melódicamente): boliviano come guano, con las patas con las manos. Era el insulto más grande que le podías decir a un niño, o si perdía en la escuela jugando a la ronda, se armaba un coro, y cantábamos: cholo, cholo, cholo, cholo, cholo..."

“... Es esta cosa de inocencia de uno, uno nunca se dio cuenta de por qué le decían cholo y boliviano. En María Elena había dos corridas de casas en las que vivían puros bolivianos, en la calle Caupolicán. Nadie quería vivir ahí. Las casas eran iguales, pero el barrio era de los bolivianos".

Asimismo, dentro de la configuración de este espacio multiétnico, según Salvador Reyes, en su testimonial libro Andanzas por el Desierto de Atacama (1963), cuando visitaba junto a su padre las oficinas inglesas, siempre "debía llevar un traje elegante porque en la Administración los hombres comían todas las noches de smoking". Pero agrega que esta práctica no tenía que ver con una pretensión desmedida, sino como una forma de mitigar el sentimiento de destierro, de retener algo de su propia cultura en medio del abandono y la pérdida de

9 Registro realizado en el invierno de 2002. 
referencialidad de las claves de su cultura originaria; sólo así puede entenderse el valor y significado que tuvo para estos extranjeros el otrora elegante Club Inglés de Taltal, en el que aún pueden observarse las finas y cómodas sillas originales, las grandes mesas de pool y billar con sus instrumentos de contabilidad, los libros de registros de socios y visitas, y la gran barra del bar.

En este desierto apropiado multiétnicamente, jerarquizado desde la división social del trabajo, y en el esfuerzo de estos hombres, descansa la carga emotiva y afectiva de una buena parte de las mayores y tal vez más tristes páginas de la historia social del país. Del desierto poblado a fuerza de permanentes migraciones, de esa hibridación cultural, arrancan las imágenes fijadas en la retina, cronológicamente correspondientes al primitivo sistema productivo de "paradas", posteriormente al Shanks, y más tarde al Guggenheim, sistemas que en su momento representan las formas de trabajo de menor a mayor mecanización, distintas formas de relaciones laborales dentro de la evolución del capitalismo local, y muy significativamente, un correlato en los términos de condición de vida de los trabajadores. ${ }^{10}$

A los primeros sistemas corresponden las imágenes de las pesadas carretas que mordían metro a metro la esterilidad de la llamada "Siberia Caliente" (Rodríguez et al. 2002), cayendo de tanto en tanto en arenales traidores; las polvaredas de tropas de sufridos asnos y mulas que transportaban toneles de agua, sacos, víveres y bultos diversos; bestias y carretas que tejieron la gran telaraña de los caminos del desierto. ${ }^{11}$

De ahí son las imágenes miles de veces reproducidas de los obreros derripiadores, los miles de hombres seleccionando a mano los materiales y con sus

10 Por esta última razón resulta altamente significativo el valor que posee la vivienda en la construcción de los asentamientos salitreros de María Elena, Pedro de Valdivia y Chacabuco, pues la vivienda obrera marca el nacimiento de barrios y formas de sociabilidad que permiten en conjunto con el resto de la infraestructura urbana dar estabilidad a la población y generar identidades particulares que se imponen sobre el aglutinante pampino.

11 Véase a este respecto las fotografías y la detallada información de trabajadores e infraestructura contenida en el Album de las Salitreras de Tarapacá de Luis Boudat y Ca., de 1889 [2001]. pesados "machos", del amplio estanque en el que hervía el caldo, que hizo tan lastimosamente célebres las caídas a su interior o las quemaduras incurables; los tiros fracasados, que, en el mejor de los casos, amputaron extremidades. También el recuerdo de los niños trabajadores batiendo caldos, los "destazadores" introduciéndose en la tierra para agrandar -con una pequeña barreta- los hoyos dejados por las tronaduras y poner el nuevo cartucho de dinamita, conduciendo carretas, o tomando el lugar de los adultos cuando faltaban brazos para faenas peligrosas o algún conflicto huelguístico se presentaba.

Esos niños y jóvenes no tuvieron nunca otra posibilidad más que mirar hacia el interior de la pampa y continuar con lo que era la experiencia laboral de su entorno, y así dar la continuidad necesaria a una cultura que enlazó en sus prácticas a muchas generaciones para engendrar un sentimiento colectivo: ser pampino y reconocerse en una tradición. ${ }^{12}$

\section{La muerte en el camino}

Así como la pampa es el lugar donde se viene a vivir, es también donde se vino a morir. Juan Floreal Recabarren recuerda que en 1911, en la región de Antofagasta, en un año se habían contabilizado 128 muertes y 930 accidentados (Recabarren 2002: 85). Estas altísimas cifras, probablemente muy superiores por el deficiente manejo de la información en esa época y las condiciones de seguridad disponibles, son complementarias a lo que ocurría en términos de prestaciones de salud, ya que los médicos eran prácticamente inexistentes en la pampa, y cuando había alguno, no tenía infraestructura y condiciones apropiadas para ejercer su trabajo, en sus visitas atendía entre 800 y 2000 trabajadores, a quienes invariablemente, cualquiera fuese su dolencia, recetaba "papelillos" (Recabarren 2002: 86).

Chacabuco, María Elena y Pedro de Valdivia, "ciudades del salitre", a diferencia de las viejas oficinas, siempre tuvieron hospital (Figura 1).

En la actualidad una muerte en el trabajo genera una gran conmoción, que va desde el jefe del cam-

\footnotetext{
12 Usamos el concepto de tradición como la recuperación de aquello que alguna vez fue pasado y que logra concretarse en el presente. Esto es, al modo de Shils (1981) y Hobsbawm y Ranger (1983), como lo recuperado que se vuelve activo, necesario y recurrente en el cotidiano de una sociedad.
} 


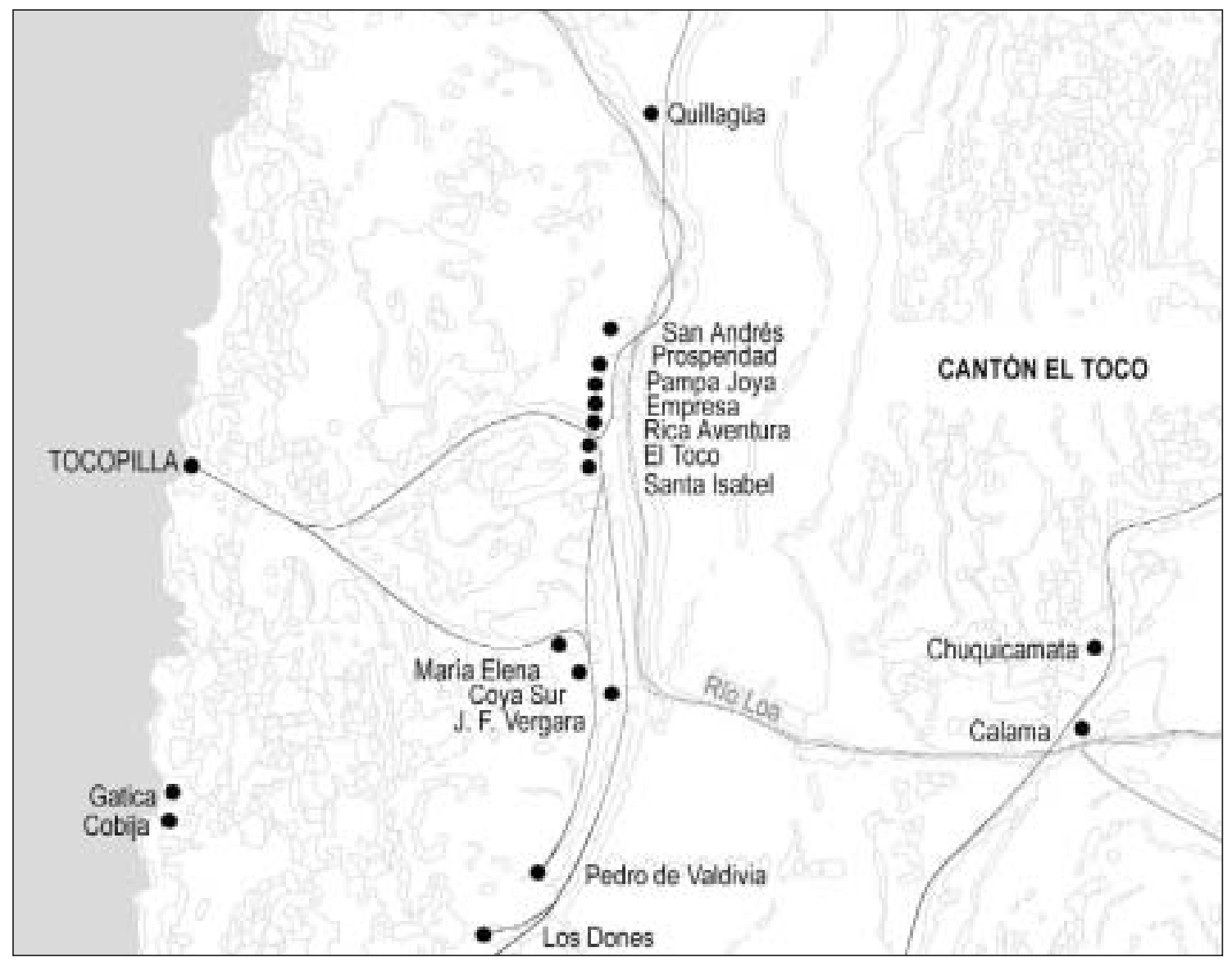

Figura 1. Mapa general de la Región de Antofagasta y ubicación de los distintos cantones salitreros y sus respectivas oficinas.

pamento hasta el último de los empleados, ya que es un hecho rarísimo y muy ocasional. En más de 50 días de trabajo de campo sólo hemos constatado dos muertes. La última, ocurrida en la primera quincena de enero de 2003, corresponde a una muerte que no debería ocurrir dentro de las actuales condiciones de seguridad industrial, pero se remarca que no involucra directamente a la empresa SOQUIMICH ${ }^{13}$-aunque se haya producido dentro de su área de explotación-, "es la muerte de un trabajador de una empresa contratista", lo que no le quita al suceso, de ninguna manera, su carácter extraordinario dentro de la cotidianeidad de las faenas actuales. ${ }^{14}$

13 Sociedad Química y Minera de Chile.

14 Uno de los elementos más importantes para la empresa Anglo Lautaro fue el tema de la seguridad, por lo que la revista institucional Pampa, desde los comienzos en 1948, hizo campañas a favor del celo con que sus obreros y téc-
Asimismo, respecto del trabajo y sus condiciones cotidianas en una perspectiva modernizadora de la industria salitrera, nada más emblemático para el período de fines del siglo XIX, que la descripción de Mariano Martínez, Historia de un esclavo, de 1895. Martínez en vívida alusión a estos exiliados atrapados en la pampa, habla de "lucha desigual, sorda y demoledora... una explotación inicua, pero creciente, que primero le escatimaba el fruto de su trabajo y después le cortaba sus aspiraciones". Señala hablando a través de Juan Bravo, que la resignación no faltó: "al recibir su plata y dejarla ligerito en manos de los pulperos, no harán otra cosa que devolverla pagando intereses"; el obrero duerme igual que un perro, sus zapatos comienzan a agrietarse en fuerza de lo resecos que se han puesto, y

nicos debían trabajar, destacando la idea de que estos siempre lamentables eventos se evitarán sólo si cada uno cumple con su deber (Rodríguez et al. 2002). 
su ropa comienza a cambiar de color para luego desgarrarse.

"Hay gente que vive -no por necesidad como los mineros, sino por inhumanidad de sus patronesen la cavidad subterránea de antiguas labores abandonadas. La conformación geológica de la pasta salitrosa exige a veces que se le vaya siguiendo el rumbo hasta cierta profundidad, donde se agota. Este es el trabajo llamado de 'cueva' en el tecnicismo salitrero, y estos hoyos abandonados se utilizan para habitación, con gran contentamiento de los capitalistas, que ahorran así madera, calamina y demás materiales de construcción" (Silva 1938: 107).

Silva se refiere a los habitantes de estas oquedades como "trogloditas", para denunciar las condiciones infrahumanas de su forma de vida.

Estas vidas mínimas, míseras y desgraciadas de muchos personajes estigmatizados y degradados por alguna discapacidad física, heredada o adquirida por algún accidente y también por actitudes de vida, inundan la literatura pampina. Por ejemplo, "el curcuncho", personaje del cuento "La ruleta mágica", pequeño monstruo jorobado, deforme, raquítico y pernituerto que causaba lástima y repulsión, a tal punto -se señala- que "mejor hubiese muerto antes de nacer", refleja trágica y grotescamente esta condición; el hombre era el hazmerreír de la Oficina, pero sus habilidades manuales le llevaron a confeccionar-silenciosamente- una ruleta que administró el fondero en medias con él, la que se hizo tan popular que fue capaz de congregar a todos los trabajadores en busca de mejorar sus escuálidos bolsillos. "El curcuncho" esperó que todos se reunieran en el garito, y éste, en colosal venganza, lo dinamitó. Cuando otros trabajadores traen la luz, "no ven más que miembros mutilados y dispersos, charcos de sangre, vísceras pegadas a las calaminas..." (Silva 1938).

No se queda atrás el relato del "Mugre" o "La mugre", del que se dice hedía de tal forma que no podría “ni subir p'al cielo cuando se muera". Era tal su costra de sebo que debería pasar toda su vida escobillándose; olía a eternidad. Sabella lo describe como un paria, de pies "sudorosos de siglos, tranqueando quizá hacía qué posada de la vida... provocaba náuseas... un machote idiota que nunca rozó el agua... Calculen la vida de un atorrante que no puede llegar a ningún puerto, a la más insignifi- cante caleta, destinado a ir y venir por las huellas; a dormir en cualquier sitio, a orillas del mar; a comer de lance... En el campamento nadie se le juntó. Dormía lejos de las carpas, botado sobre unos sacos, tapándose con papeles..." (Sabella 1997: 231-232).

Lo señalado contrasta con la estirpe del administrador. Este, que de cuando en cuando sale a visitar su gran feudo -las calicheras-, lo hace siempre tocado con su cucalón, de tenida alba, montando un caballo cuyas riendas toma delicadamente con sus manos enguantadas (Martínez 1895).

Muchas fotografías refuerzan esta idea del británico elegante y adaptativo, y el paroxismo de esta actitud ganadora ante la vida se ve reflejada como en ninguna otra imagen en el hombre que con sombrero hallulla y traje de baño a rayas boga en su bote, bajo el feroz sol de la tarde, en la piscina de una anónima oficina nortina (Figura 2).

Lo importante, a partir de esta descripción, es recalcar la fuerza y la pervivencia de un imaginario de la pampa que se resiste a morir. Imaginario que, inclusive, puede atrapar a antropólogos acostumbrados al "yo testifical", y predeterminarlos a encontrar aquello que han ido a buscar, aquello que esperan encontrar, aquello de lo cual hablan sus informantes y que tal vez ya no se encuentre allí, salvo en su memoria, y en el caso extremo, en su imaginación.

Salvando esta trompe l'oeil, tal vez lo único que quede de este imaginario sea el concepto pampino de una estoica lucha por afianzar un territorio que ya no existe, un imaginario que se afinca y sostiene a cuenta de jirones y fragmentos de memoria,

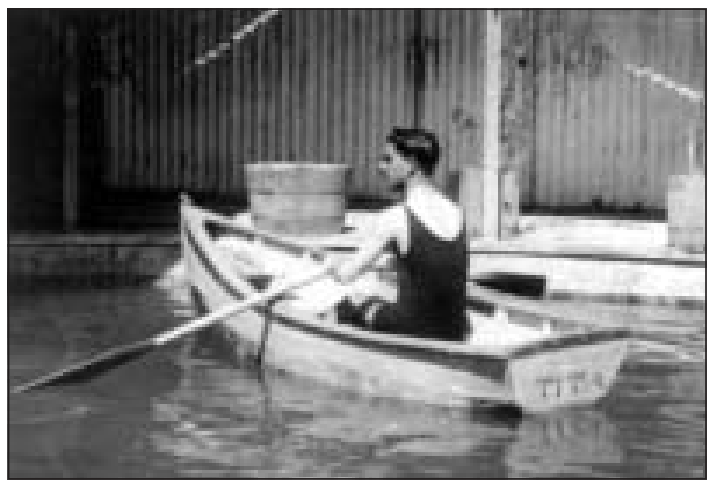

Figura 2. Hombre bogando en una pileta (Colección Museo Histórico Nacional). 
los que poco a poco, para emplear la expresión de Baudrillard (1993), se convierten en un simulacro.

Indudablemente, si hoy se busca en María Elena esta épica de la colonización del desierto llevada a cabo por rudos conquistadores, bajo infaustas condiciones de trabajo, no se corresponden los elementos del imaginario con los referentes de lo real actual y lo real fundacional. Se trata del territorio sin mapa, según la metáfora de Baudrillard tomada de Borges; el espacio en el que no se encuentran las coordenadas para fijar los límites para contener las imágenes con las que debe ser pensado un mundo. Se tiende una trampa a nuestro ojo, y nuestro ojo es engañado.

En este sentido, el cambio de la cultura pampina viene dada por varios ejes simultáneos, los que han ido, poco a poco, ocultando la imagen del pasado asociado a las condiciones de trabajo y de vida infrahumanas que dieron origen a las relaciones capitalistas de producción, tempranas contradicciones sociales, al movimiento social, importantes líderes sindicales, mártires, la prensa obrera y los principales partidos políticos de raigambre popular. Quizá, dentro de estos ejes uno de los más emblemáticos, pero probablemente el más olvidado sea el cambio tecnológico y el aumento de las condiciones de seguridad a partir de la implementación del sistema Guggenheim por primera vez, justamente en María Elena, el año 1926.

Toda la literatura pampina, casi sin excepción-destacando a Luis González Zenteno (1954, 1956), Víctor Domingo Silva (1938), Volodia Teitelboim (1996), Andrés Sabella (1997), Mario Bahamonde (1945, 1951), Julian Cobo (1971), Salvador Reyes (1963), Pablo Neruda (1967a, 1967b), Hernán Rivera Letelier (2002) y el libro testimonial de Mariano Martínez (1895), hacen hincapié o aluden con mayor o menor intensidad en los elementos trágicos que conforman la ruta de la vida del poblamiento de la pampa, partiendo por el engaño en la forma de pago en cuanto a la no cancelación del trabajo contratado en dinero nacional, sino en ficha-salario. Esto se transforma en temprana fuente de protesta, la que se asocia a un importante número de víctimas, cuyo recuerdo más emblemático se encuentra en la masacre de la escuela Santa María de Iquique.

Rivera Letelier (2002), el más contemporáneo de los escritores pampinos, quien vivió en las ofici- nas salitreras, captura el imaginario de la pampa de 60 o 70 años atrás y lo reinstala en el presente. Pero, temáticamente, no asume el cambio, inclusive parece casi imperceptible el sistema de trabajo de tipo Guggenheim que se impone en las oficinas de Pedro de Valdivia y María Elena. El imaginario reinstalado para quienes se han solazado con sus obras no puede ver la modernidad de la industria salitrera y asumir, por ejemplo, que los "pampinos de hoy" ven televisión satelital, usan teléfonos celulares y compran automóviles $0 \mathrm{~km}$. Sin embargo, aunque cultiva los mismos tópicos, toma distancia de los otros narradores, y es quien más da un aire festivo a la vida en la pampa, recordando cuestiones de la vida cotidiana que hemos podido registrar en nuestro trabajo de terreno casi con exactitud en sus relatos, partiendo indudablemente por el no reconocimiento del nombre de pila con que hombres y mujeres fueron bautizados. Todo hombre y toda mujer que se precie como pampino y pampina, que se sienta hijo o hija de esta tierra lleva por nombre un apodo. ${ }^{15}$

Entre muchas otras cosas que se pueden señalar desde el discurso literario, está la descripción de las viviendas con sus adobes, calaminas y el hacinamiento. En este sentido, baste sólo recordar que desde el punto de vista de la vivienda se considera - de modo parcial- que en el cantón Central llegaron a vivir "alrededor de 70000 personas, de las cuales 28000 eran obreros", muchos de ellos campesinos y otros de países vecinos, los que ocuparon unas 7600 unidades habitacionales, con unos 3500 cuartos para solteros, llegando a establecerse un número superior a seis personas por unidad (Garcés 1999: 43).

Asimismo, la situación de la alimentación, el trabajo infantil, la condición de la mujer en un espacio esencialmente fálico, con roles extremadamente

\footnotetext{
15 Por ejemplo, "el Perlina" (alusión a un detergente usado en la pampa) o "Rinso" (también un detergente), eran los apodos dados al personaje que se caracterizaba por su falta de aseo, el que solía usar su ropa hasta que ésta se rompía por el uso, porque no se la quitaba jamás; los panaderos eran llamados "los murciélagos", pues antiguamente en función de su oficio permanecían despiertos de noche; "el siete ternos" era un obrero caracterizado por su elegancia, el cual solía cambiarse muchas veces durante el día sus ropajes, costumbre inusual para la época; o, entre muchos otros, "el viandero": trabajador que realizaba dos turnos, y que con este esfuerzo adquirió una moto alemana y ahorró seis millones de pesos, los que guardaba en su casa, hasta que un incendio acabo con su moto y su dinero.
} 
diferenciados, muestran la pampa trágica y doliente en la que se escribe buena parte de la historia social de este país. Silva (1938), por ejemplo, señala como lema respecto de la mujer: "¡Sufrir, siempre sufrir: con el padre, con el hermano, con el marido, con el compañero, y luego con el hijo, esa es tu dote, ese es el número fatal que te deparó el azar, misérrima mujer de nuestro pueblo!"' (Figura 3).

Ese es el mundo que se fue inexorablemente. El que se perdió para siempre, pero que sigue siendo pensado por algunos desde la nostalgia, fijando la mirada en el hombre rudo e irremplazable; el macho, el sostenedor, el de la grandeza, el que dejó su salario en los míticos burdeles, en la cantina o en el garito, el que se dinamitó por amor. También el que fue engañado por el enganchador y explotado por su patrón; el que en los comienzos recibió por salario una ficha para ser cambiada en la pulpería, cuando esperaba moneda nacional para enviarla a la familia que estaba en el sur.

Cuándo se piensa en el mundo del salitre o en la oficina salitrera se anticipa la imagen de la explotación, de una vida espantosa y llena de miserias (Figura 4).

Por ello, nadie que se haga parte de este imaginario puede sospechar los procesos de modernización desarrollados en la industria del salitre. Por ejem- plo, actualmente los ejecutivos de SOQUIMICH, la empresa monopólica de salitre a nivel mundial, cuenta con el diseño de lo que será la construcción de un "hotel" con capacidad para alojar a 1700 personas en las faldas de un pequeño cerro en la cercanía de la ex Oficina Vergara, libre de toda contaminación, que albergaría a sus trabajadores en turnos de siete por siete días, en habitaciones con dos camas, en las que nunca se toparán los compañeros de cuarto; con salas de cine, lugares de recreación y casino. Como señala Patricio Contesse, el Gerente General de la compañía, "no será cinco estrellas, pero algo similar" (Revista Norte Minero 2002: 18).

Es la misma empresa la que se esfuerza en reinventar la vida. Durante el año 2003 incorpora la noción de House Keeping, intento por transmitir a los trabajadores la idea de la casa limpia y ordenada, como una cuestión de cultura laboral dentro de todo el quehacer de la planta (ver Revista Mundo SQM, Marzo-Abril-Mayo, 2003).

Ciertamente, esto nos aparta bastante del imaginario "clásico" de lo que "debería ser" la "vida pampina". Asimismo, otro eje significativo de ruptura con el pasado está dado por la incorporación de las variables ambientales, tanto a los procesos productivos como en todo aquello que afecte la vida del campamento.

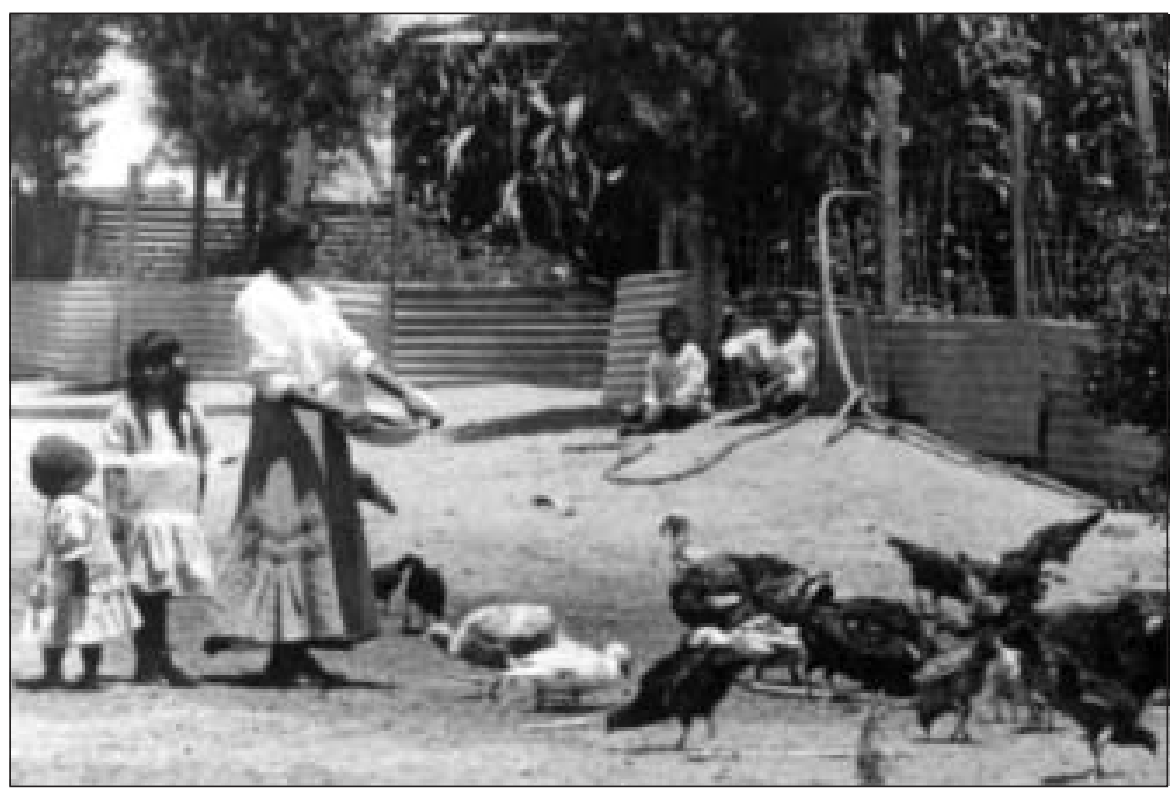

Figura 3. Mujer y pavos (Colección Museo Histórico Nacional). 


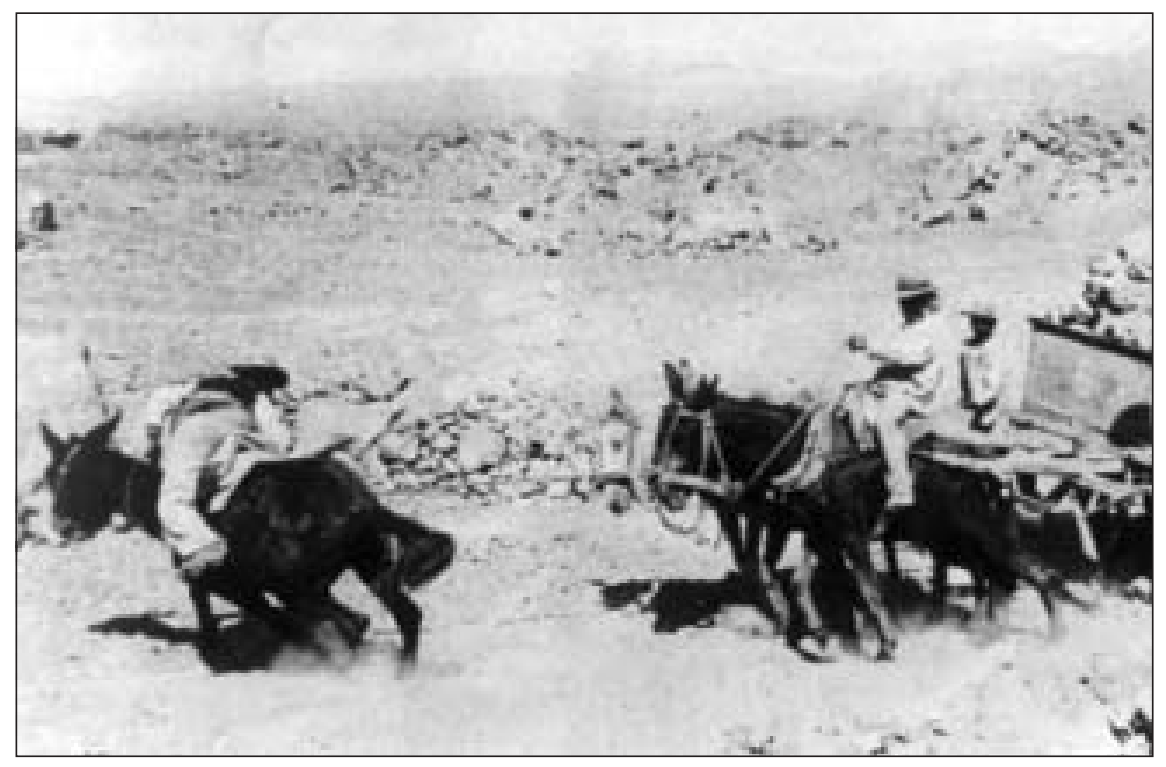

Figura 4. Carreta calichera. Reproducción cedida por el Sr. Eduardo Ramos.

Sabemos que la naturaleza para el antiguo pampino se establecía como una clara y feroz amenaza, como una entidad despiadada, que no transaba; hombre y naturaleza se encontraban en una lucha continua, en la que esta última se llevaba la mejor parte. El hombre peleaba con ella para extraerle su riqueza al precio de una constante batalla de desgaste, de su propio desgaste.

Pero, repentinamente, esa naturaleza invencible se transforma en una entidad vulnerable, que debe ser protegida, cuidada, hasta restaurada en el daño que el hombre le ha infringido. Traslape de polaridades entre víctima y victimario.

A su vez, el hombre debe adaptarse a esa naturaleza, y a su vez, se debe proteger de su propia acción desbocada, desaforada por la propia naturaleza. A este tipo nuevo de acción humana se la llama polución, o contaminación.

En este contexto de adaptaciones el hombre aparece también como un sujeto frágil a la "mala acción" del hombre sobre su entorno, entorno que lo incluye necesariamente. Debe ser protegido, y si es dañado por la contaminación, de cualquier orden, la máquina productiva debe pagar y pagar.

Cuando el viento se vuelve incontrolable, "el molino, inmediatamente, cesa de triturar el mate- rial". ${ }^{16}$ Pero, la polvareda que se deja caer sobre "María Polvillo", apodo histórico con el que ha sido conocida la Oficina María Elena, se mitiga con Road Mag, producto de la Compañía destinado a estabilizar los caminos de tierra, evitando la elevación de material particulado.

Así, dentro de la especulación ominosa que se da en la comunidad sobre el destino de la última oficina salitrera, tanto en las familias como entre los trabajadores activos y los jubilados, aún cuando no se debe confundir el cierre del campamento con el cierre de la salitrera, una razón posible para la desaparición de María Elena es el alto grado de contaminación a la que están sometidos sus habitantes. Argumento que, aunque ningún trabajador conozca la verdadera razón, probablemente haya sido uno de los tantos utilizados para decretar el cierre de su homónimo Pedro de Valdivia, pues la densidad de la nube de polvo que se dejaba caer cada tarde, impedía ver del otro lado de la calle.

El rudo pampino, curtido por la historia, ahora, podría ser aniquilado por el polvo de la pampa.

¿Era posible pensar hace algún tiempo, digamos 30 años, en algo tan sutil como la contaminación?

16 Entrevista realizada al Sr. Jorge Araya, Jefe de Campamento de María Elena. 
La cuestión no es menor. Queremos hacer la diferencia entre este "Modelo Ecológico" y el de "Seguridad Laboral", para que no haya duda de su especificidad.

La Seguridad Laboral se introduce lentamente después de la Segunda Guerra Mundial; ésta protege al hombre de la feroz naturaleza de la pampa y sobre todo, protege al trabajador de sí mismo, o de sus máquinas. El ecologismo protege a todo ser vivo o inerte, de la acción de cualquiera, dentro de una regulación que se define como "ambiental". Es algo nuevo e inédito dentro de las relaciones del hombre pampino con su entorno de sol -abrasador, mortal- y viento.

Ahora, la amenaza es el hombre. Pero, a su vez, es un hombre al que también hay que proteger de su trabajo y del efecto de éste sobre él, sobre la comunidad y sobre su entorno, junto con proteger la naturaleza y restaurarla. Así, la feroz victoria de la máquina productiva sobre la pampa, es la derrota de todos: producción, hombres y naturaleza. La cruel pampa que "hacía a los hombres", ahora los vuelve a hacer, a partir de un pacto de mutuas agresiones controladas, lo que los sofistas empresariales llaman "desarrollo sustentable", cuestión que consecuente con esta lógica debería poner fin a las nubes de polvo que ciegan la vista de los eleninos a la caída del sol.

Durante el año 2002, SOQUIMICH diseña un Sistema de Gestión Ambiental, buscando alinearse con las "crecientes expectativas de desempeño ambiental que se generan, cumpliendo los requisitos y las normas que -sobre estas materias- se establecen en el país y en el mundo". Esto significa, en voz de su Gerente General: "compromiso con la protección del medio ambiente y la salud de las personas relacionadas con sus operaciones" (Revista SQM 8, 2003).

El pampino es un nuevo hombre que ya no carga sacos de 50 o más kilos, no sufre el infierno de los "cachuchos"17, ni la amenaza de un tiro que explota a destiempo: es un hombre que necesita del aire acondicionado y dieta balanceada, que ha transitado literal y metafóricamente del "cocho"18 al salad bar.

17 Se trata de un estanque rectangular, en el que se disolvía el caliche por medio del vapor.

18 Bife con harina tostada, cebolla frita, tomate, huevo y papa.

\section{3: el territorio sin mapa}

El trazado por parte de SOQUIMICH de un hotel para trabajadores sin familia, se concrete o no, cuestiona uno de los elementos más emblemáticos del mundo pampino: el lugar. Esto es, en primer término, la identificación del trabajador con su oficina, aunque sabemos que muchos -en el pasado y en el presente reciente- circularon por varias de ellas, a medida que se iban cerrando; $y$, en segundo término, la dependencia de la pampa, del paisaje.

Entonces, enfrentados a un proceso de modernización de la empresa salitrera de gran envergadura, con trabajadores con sistemas de trabajo que ya no necesitan hacer la vida en la pampa y cuyas familias pueden radicarse en ciudades cercanas o incluso en otras regiones, se produce un proceso de quiebre con los espacios de sociabilidad tradicionales en los que se recrea la cultura pampina. De modo que se impone necesariamente la pregunta de hoy: ¿quién es un pampino?, ¿quién es un pampino en la actualidad? o ¿qué es lo que los convierte en pampinos?

En este sentido, hay una disolución de tres elementos intrincados y fundantes de la cultura y tradición pampina: explotación salitrera (con su ferrocarril y puerto de embarque), emplazamiento industrial y pueblo. La historia del salitre es la historia de la cercanía de los mismos, y por ello, de la humanización del territorio "estéril" en los espacios cotidianos, en los que como hemos sostenido destacan la pulpería, la actividad deportiva y los "ranchos" (Rodríguez et al. 2002).

La disolución de esta dimensión se ve refrendada en la idea de que por primera vez los pampinos de María Elena tienen una preocupación especial por postular al Subsidio Habitacional. La aspiración a ser propietario de una vivienda de 150 UF, los saca del escenario de la pampa. ${ }^{19}$ Sus prioridades son acceder a una vivienda, privilegiando en primer lugar la IV región, y dentro de ella Ovalle, Punitaqui, Vicuña, Illapel, Monte Patria, San Marcos; sólo secundariamente se contemplan grandes ciudades como Arica, Iquique o Antofagasta como posibilidad de nueva radicación. ${ }^{20}$

19 Al ser SOQUIMICH la dueña de los terrenos en los que se emplaza el pueblo no existe ninguna posibilidad de construcción de viviendas en este lugar.

20 Registros de campo correspondientes a la temporada de enero de 2003, en María Elena. 
La elección de estas pequeñas ciudades de la IV región, se debe a que el valor del $\mathrm{m}^{2}$ de terreno es más barato que en cualquiera de las otras regiones y ciudades, y porque muchos de estos pampinos son originarios de estos lugares y aun mantienen allí parentela. Pero, aún más significativo resulta el que el SERVIU ${ }^{21}$, haya entregado en el año 2000 el equivalente a 7000 UF en subsidios habitacionales a los habitantes de María Elena, favoreciendo aproximadamente a 50 familias. Si esta cifra se valora y se proyecta, calculando a un promedio mezquino de cinco personas por núcleo familiar, tenemos que un $3 \%$ de la población ya está en condiciones de emigrar del pueblo, al que se suman quienes ya han obtenido dicho subsidio con anterioridad y quienes lo obtendrán en el curso de los próximos años. ${ }^{22}$

En la actualidad, la construcción del imaginario de los habitantes de María Elena no tiene referente sincrónico. El referente señalado más arriba y recreado a partir de múltiples publicaciones se deshace a cada momento y en todos los espacios, pero debe ser retenido para poder testificar que se es pampino, que se es de María Elena, la última oficina salitrera o campamento salitrero, como también se le llama.

Para confirmar y autentificar el imaginario de la pampa se debe recurrir, por ejemplo, a viejas fotografías como elemento testimonial. A todas aquellas del siglo XIX y comienzos del XX que fundamentalmente retratan tormentosas y sufridas faenas a pleno sol, con ropas a veces harapientas, con niños revolviendo el caldo en las bateas, con mulas desplegando infinitos esfuerzos para mover una carreta que el arenal intenta devorar. Esta impresión temprana y su reproducción se convierte en una forma privilegiada de testimoniar: "así era la pampa", "así era el trabajo", "esto se forjó con el macho de 25 libras", "así éramos".

Hay un fotógrafo que colecciona ese pasado, que permite recordarlo, que lo protege del olvido y que denuncia usurpación y apropiación indebida de aquello que es memoria pampina; denosta contra

21 Servicio de Vivienda y Urbanismo.

22 No es extraño que en nuestro trabajo de campo se nos señale con recurrencia la propiedad de un bien raíz en alguno de los lugares indicados, o en otros, como Alto Hospicio en Iquique. los que transan las fotografías y se deshacen de ellas como si sólo fueran un objeto material. Es el mismo que añora los viejos libros y planos que desaparecieron de la biblioteca de Pedro de Valdivia, la que muchos reconocen como imponente y bien cuidada. Eduardo Ramos, quien hace gala de una pléyade de reinas y aspirantes a cetros de belleza en su escritorio en el Museo Municipal de María Elena, puede encandilar con reproducciones de fotografías históricas y etnográficas durante todo un día al más versado de los hombres preocupados por los temas pampinos.

"Rojitas" no le va en zaga. Fotografía cada rincón. Consigue imágenes del pasado lejano y reciente con amigos, familiares y aficionados. Intercambia. Arrastra al presente el auge y declinación de la industria del salitre, trayendo el pasado y los recuerdos. Ricardo Rojas, entre fotografías, cajetillas de cigarrillos y objetos diversos hace una invitación lúdica a buscar las huellas del paso de los días. Por eso quiere retratar el paso del tiempo. Quiere fotografiar cada esquina, cada edificio y cada lugar de María Elena, ubicando los mismos lugares y construcciones que en el pasado fotografiaron los hoy anónimos paisajistas. Empuña su cámara sobre construcciones y calles y observa con un halo de nostalgia cómo se ha transformado el paisaje... Taxis, camionetas, vehículos particulares, buses y camiones recorren el pueblo donde sus ojos pueden ver aún las carretas que aparecen en su colección de fotografías (Rodríguez 2001; Alvarado 2002).

La señorita Riquelme, en algún momento secretaria de la empresa SOQUIMICH, ostenta la mayor colección de botones conocida en la pampa. Ha recorrido junto a su padre todas las oficinas buscando estos tesoros de distintos colores, texturas, diseños y materiales. Ordenados con paciente dedicación, puede exhibirlos y arrancarles secretos. Roberto Garay, adolescente reñido a muerte con la escuela, pero autodidacta en su afición por la colección de cajetillas de cigarrillos, "cachureando"23 entre los basurales ha logrado armar una inapreciable colección de éstas, estableciendo sus orígenes, la identificación con oficinas, con algunos de sus administradores y su ubicación espacio temporal. Encuadernadas en varios álbumes, compar-

\footnotetext{
23 "Cachurear": revisar los depósitos de materiales viejos o basurales para extraer algún objeto que pueda tener valor personal o transable.
} 
te su interés con otros coleccionistas a quienes ha preparado segundas y terceras colecciones, llegando a intercambiarlas con otros objetos. Se ha negado a deshacerse de ella cuando algún afuerino le ha ofrecido comprársela.

Por su parte, el "Keysi", no les va en zaga. Tiene la mejor colección de carteleras cinematográficas y afiches de películas, aunque muy probablemente no ha visto ninguna de ellas. Han llegado a sus manos desde los basurales, encontradas en viejos documentos familiares o conseguidas entre los amigos; todas se encuentran perfectamente ordenadas en carpetas y cuadernos. No se queda atrás de Garay, pues goza de una no despreciable colección de cajetillas de cigarrillos. Asimismo, impresiona su afición por las botellas de cerveza cuyo contenido ayudó a saciar la sed y olvidar las penas después de las fatigosas jornadas de trabajo.

El profesor Riquelme es reconocido por toda la comunidad por sus eruditos conocimientos sobre la vida pampina y por su invaluable colección de fichas-salario; celoso de las mismas, sabedor de todas las historias que esconden, afirma con dignidad: "jamás compré una ficha". Todas fueron conseguidas en sus aventuras arqueológicas en las desarmadas oficinas. Perfectamente ordenadas en álbumes, organizadas según el cantón, el lugar de procedencia y la antigüedad; las goza como un pirata que introduce las manos en un cofre reluciente y lleno de doblones.

En este espacio recordatorio, hasta un alto ejecutivo de la empresa SOQUIMICH inicia una incipiente colección: calamorros, balas y relojes antiguos adornan su oficina.

La máxima expresión del coleccionismo se encuentra en el Museo Municipal de María Elena, organizado desde hace más de 15 años por Claudio Castellón, quien desde su afición por la arqueología recolectó innumerables piezas correspondientes a la vida del salitre. Tomadas éstas de diversas oficinas, y otras donadas por distintas personas, adquieren forma en una organización caótica, la que puede ser leída en cualquier orden, pues no tiene principio, fin, ni tiempo. Sólo es una exposición salitrera, testimonial, evocativa, nostálgica, materialmente reveladora del imaginario.

Ahí pueden encontrarse todos los elementos domésticos: ollas, platos, cocinillas, cajas de fósforos, tenedores, cucharas, cuchillos, molinillos de café, planchas de ropa y una máquina de coser; latas de sardinas importadas, tapas de envases de refrescos, botellas de agua gasificada, de cerveza, de bebidas gaseosas y de champagne. También envases de jabón, blanqueadores de ropa, polvos dentífricos y tubos de pasta dental, hojas de afeitar con sus respectivos envases, máquinas de rasurar, frascos de lociones; no faltan también los rústicos juguetes de latón, bolitas de piedra y cristal, muñecas. Asimismo, todo tipo de ropa y utensilios de faenas: calamorros, loncheras, cascos de seguridad, palas, cantimploras, tachos de "choca" ${ }^{24}$, mecheros. La impresionante y heterogénea colección contempla fichas-salario, coronas de cementerio, candados, llaves, parlantes, pupitres escolares, libretas de calificación, libros de estudio de escuela primaria, recortes de periódico, revistas de moda, camisetas de clubes deportivos, estandartes de escuelas desaparecidas, cascos de compañías de bombero, y hasta agujas de vitrola con sus respectivos envases. No escapan a este deseo de retenerlo todo una máquina de escribir Underwood y un disco de vinilo de un joven y piloso Julio Martínez, narrando episodios del mundial de fútbol del año 1962.

Refuerza también esta mirada hacia el pasado la gran cantidad de vestigios materiales dispersos en todos los caminos de la pampa. En María Elena, en el patio de las viejas locomotoras y carros ferrocarrileros, éstos se alzan como verdaderos monstruos, ayudando a activar el imaginario sobre viajes interminables y tragedias. En las viejas oficinas hay chatarra por todos lados; las estaciones abandonadas de ferrocarril son insumos permanentes para refrendar la propia historia.

En este contexto, es importante hacer notar que los coleccionistas son grandes fetichistas, "pues cada símbolo permite urdir el relato con deseos, recuerdos, anécdotas, acontecimientos. Cada imagen o cada pieza conlleva una diseminación diacrónica de este espejo en el que leen” (Rodríguez 2001: 74).

Así como el recuerdo se activa a través del coleccionismo, otro eje sustentador del imaginario es el relato cruzado. Las narraciones registradas en el trabajo de campo se van permanentemente autorefrendando, entrecruzando y densificando con elementos míticos, históricos y hasta delirantes. A tal punto que, por ejemplo, cuando el "ñato" Esquivel, púgil retirado, va a visitar su hoy inexistente casa,

24 Colación seca que se consume al mediodía. 


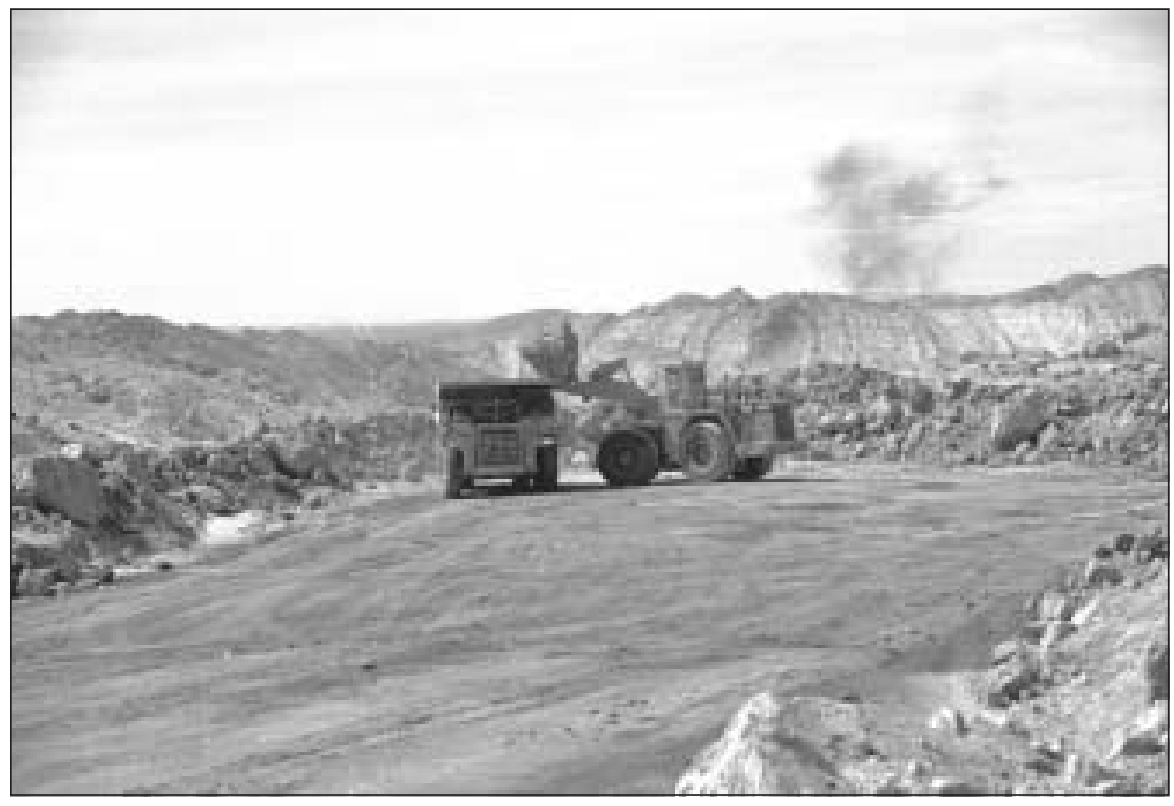

Figura 5. Camión en el frente de explotación.

al pueblo de Vergara, y observa la plaza con sus árboles caídos, y otros que aún resisten en pie, parados como "mástiles que dieron vida" -según algunos- al más hermoso de los pueblos salitreros del "grupo Toco"25, puede afirmar con un hálito evocativo: "aún están verdecitos". Sin embargo, desde el cierre de Vergara éstos yacen en el abandono, muriendo inexorablemente, sin esperanzas, como el pueblo mismo. Están secos. El desierto hace rato los atrapó.

El entrecruzamiento de las narraciones no sólo tiene que ver con quienes son de la misma oficina. El dato se enriquece en la medida que el imaginario se va constituyendo con aportes coyinos, vergarinos, pedrinos y eleninos. Cerrada una oficina del "grupo Toco", todos se van refugiando en otra. Hombres y mujeres de Coya, Vergara y Pedro de Valdivia se establecen en María Elena, asiéndose desesperadamente a la última oficina como náufragos a una balsa.

\section{Hacia la transformación}

Relacionado con este desperfilamiento del imaginario, destaca el fin del trabajo rudo, del esfuerzo extremo y el desarrollo de nuevas tecnologías. Por

25 Grupo de oficinas que tienen como cabecera de embarque del nitrato al Puerto de Tocopilla. ejemplo, en el "frente de explotación", para operar solamente la draga se necesitaban 45 operarios. En la actualidad, para todo el proceso en el "frente de explotación" sólo se necesitan seis. Cargadoras, chancadoras y correas de conducción de material son vigilados y manejados por computadoras, al igual que los camiones, donde estos sistemas anticipan las posibles fallas mecánicas de estos verdaderos oasis climatizados; cada vez que el aire acondicionado falla, el operario deja de trabajar hasta que éste sea refaccionado y le devuelva un ambiente adecuado. Esta situación contrasta absolutamente con las antiguas condiciones de trabajo de los calicheros, que debían soportar a pleno sol, temperaturas muchas veces superiores a $\operatorname{los} 40^{\circ}$ (Figura 5).

En el pasado, además, las máquinas debían ser acompañadas por sus mecánicos y por el personal de mantención permanentemente: los insustituibles graseros, que cuidaban de que el excesivo polvo y sequedad no deterioraran de las piezas eran verdaderos celadores de la maquinaria. Ya no existen. ${ }^{26}$ También se extinguieron.

26 En el año 1953, sobre la base de una producción anual de 1.700000 toneladas métricas, se necesitaban nada menos que 24000 hombres. En abierta tensión con la industria del salitre sintético, se señala que mientras en ésta se requiere tan sólo un hombre para producir una tonelada, en la pampa se necesitan 48 para alcanzar tal cantidad (Revista Pampa $\mathrm{n}^{\circ} 65$, agosto 1953 ). 
De este modo, en el "frente de explotación" había una sólida comunidad de trabajo que desapareció; eran esos mismos compañeros los que después compartían en el pasaje, en el deporte y en la cantina; o se encontraban en el salón de baile, en el teatro, en la plaza o en el sindicato. Estos hombres, muchos de ellos no calificados para los desafíos económicos y productivos de la nueva empresa salitrera, que fueron superados por la tecnología, son los que hoy -con fortuna- se encuentran prestando servicios menores, por lo general para una empresa contratista.

A partir de esta pérdida del sentido colectivo de la comunidad del "frente de explotación", y de la introducción de la tecnología que desnuda la baja calificación del antiguo obrero pampino, puede entenderse la lapidaria sentencia: "Somos obsoletos Farías. Convéncete". Esquivel, nuestro informante, pensaba ya en los años 60 que el mundo de la tecnología superaría la mano del hombre. Su fantasía se confunde con la literatura; no sabe si lo pensó, lo leyó o lo vio en alguna película, pero creía que si en ese entonces se trabajaban 24 días al mes, después sólo lo harían 15; más tarde, con nuevos avances la mitad del tiempo, hasta llegar a 4 días por mes. Al final, cuando el trabajo se reduce a sólo dos días, ya no se necesitarían hombres. La máquina lo haría todo, y al Estado le correspondería pagar los salarios para vivir. ${ }^{27} \mathrm{El}$ tiempo parece darle la razón: cada vez se necesitan menos hombres para desarrollar las antiguas faenas, la máquina los ha desplazado. Está obsoleto. Como Farías, como tantos.

En este sentido resulta ilustrativa la anécdota del "saco" pampino. El rudo pampino, según Esquivel, luchó por mejorar sus condiciones de trabajo y demandó que los $80 \mathrm{k}$ de peso disminuyeran "porque [su carguío] a los perlas les daba problemas de lumbago". Este se redujo a $40 \mathrm{k}$ y luego a $25 \mathrm{k} .{ }^{28}$ Sin embargo, esta demanda se tradujo en la irrupción de la fuerza laboral femenina, la que ya no sólo podía ensacar, sino también "tirar sacos" 29 , cuestión nunca antes vista en la pampa, pues se trata de un espacio laboral esencialmente masculino. Ade-

27 Registro realizado en María Elena, en el invierno de 2003.

28 Según Floreal Recabarren, una de las formas de explotación en las faenas y que derivaba en afecciones cardiacas, era el acarreo de sacos de $120 \mathrm{k}$ (2003: 33).

29 Forma de referirse al carguío de sacos en los camiones. más, las mujeres realizan labores de aseo, de manera formal, con contratos de trabajo y previsión, en los laboratorios, oficinas y planta; también, aunque de manera no formal, realizan labores de aseo, planchado y lavado de ropa en casas de contratistas, aunque se reconoce esta actividad como muy mal remunerada. Asimismo, una buena fuente de ingresos para la mujer se ha convertido el dar alimentación en sus casas a los trabajadores de las empresas contratistas.

Orgullosa, Maritza Oyanedel, ingeniero metalúrgico, se transforma en la primera mujer contratada como Operadora de Consola de la Planta de Acido Bórico. Cascos, antiparras, zapatos de seguridad, uniformes, una destacada señalética y modernas camionetas y buses que dejaron atrás a las "jabas" de ferrocarril que transportaban al personal, son parte de la cosmética de los nuevos hombres y mujeres de la pampa.

Farías y Esquivel trabajan para una empresa contratista. Con sus overoles rojos, signo de nula calificación, barren la materia prima que cae de uno de los procesos productivos. Mientras, las mujeres "tiran" no sólo sacos de $25 \mathrm{k}$, sino que desde 1995 conducen camiones mineros de 40 toneladas, palas y cargadores, con un éxito que, una vez adquirida experticia, les ha permitido aspirar a ganar mejores salarios en otras compañías mineras como El Abra. ${ }^{30}$

Esto ha implicado que la mujer se ha liberado en alguna medida de su tradicional y rígido papel de dueña de casa, madre y cocinera. Hay una queja masculina: "las mujeres ahora compran la comida lista, la calientan y la sirven; ya no cocinan... ahora lo tienen todo listo". La antigua comida pampina cocinada en casa como el "cocho", ha sido reemplazada por "comida para pájaros" o "comida de jinetes", la misma que creen se da en el casino de SOQUIMICH. ${ }^{31}$

El pampino es un nuevo hombre que ya no carga sacos de 50 o más kilos, no sufre el infierno de los "cachuchos", ni la amenaza de un tiro que explota a destiempo, es un hombre que necesita del aire acondicionado y dieta balanceada.

30 Entrevista realizada al Sr. Jorge Araya, Jefe de Campamento de María Elena.

31 El casino de SOQUIMICH es conocido por algunos pampinos como la "pajarera". 
La distinción gastronómica no por cotidiana deja de ser importante. Por el contrario, más que el recuerdo del plato pampino por excelencia, el " $\mathrm{co}$ cho", lo perdido y evocado es el consumo de los productos importados que los hacía distintos, en un país que no conocía de alimentos que no fueran nacionales. Hasta el día de hoy se apela a la disponibilidad de alimentos que llegaban en los vapores directamente a la pampa. El pampino de María Elena y Pedro de Valdivia disponía de alimentos de la misma procedencia que los que consumían los administradores, lo que es leído como un acto generoso y de preocupación por sus condiciones de vida, aunque sabemos, el "gringo" nunca estuvo realmente cerca. Por eso, si algo se ha perdido, es el pequeño paraíso que significaba la pulpería.

Otro eje significativo de ruptura es la discontinuidad del proceso de socialización. En el pasado pampino, con mucha fuerza en el sistema productivo de "paradas" y el Shanks siempre existió el aprendiz que daba continuidad a los roles, por lo que las imágenes de éste en las distintas faenas no son extrañas. El niño se hizo hombre sólo mirando hacia adentro de la pampa, porque era parte de una cultura homogénea en el sentido etnológico de memoria, ya que se "vivía de acuerdo a ciertos códigos y existía un comportamiento expresado en relación a su uso" (Todorov 2000), de modo que estaba muy claro lo que se debía y podía hacer. Más tarde, implementado el sistema Guggenheim en María Elena y Pedro de Valdivia, y siempre bajo un horizonte que permitía mirar hacia adentro del campamento, los jóvenes se incorporaban como ayudantes en sus períodos de vacaciones escolares. Pero además, dentro de la administración norteamericana tenemos una particularidad adicional: hay una política oficial de parte de la empresa que alienta a que los jóvenes concluyan sus estudios y que las familias y el sindicato se preocupe en particular de ello.

Por ejemplo, el editorial de la Revista Pampa de marzo de 1949, se encuentra orientado a realzar el valor de la educación como una política proyectiva, y de paso a perfilar lo que debe ser un dirigente sindical criterioso y preocupado de la suerte de las familias de los asociados, en oposición a aquellos conductores "sin sentimiento nacional". Se alienta:

"la posibilidad y conveniencia de que los sindicatos obreros destinaran una cuota de los beneficios que la Ley les otorga, como participantes de las utilidades de la industria, a mejorar la capacidad técnica de los hijos más aventajados de los propios sindicatos".

Se trata de una explícita insinuación para que quienes hayan destacado en sus estudios primarios y tengan las mejores capacidades, fueran financiados por el sindicato para proseguir estudios técnicos sin que esto implique un desembolso adicional para las familias. Pero además, el estar ocupados o haciendo algo, se expresa en que los niños de la pampa viajen de vacaciones a las playas de Antofagasta al concluir el año escolar, cuestión que se realiza con el apoyo de los ciudadanos de Pedro de Valdivia y María Elena, la empresa y diversas organizaciones sindicales y sociales, ya que el cuidado de los niños “...es la preocupación primordial de cada sociedad, ya que formará ciudadanos para el mañana, desarrollando una raza sana y pujante..." (Revista Pampa, diciembre 1948).

"Nadie estaba de pará", recuerda el profesor Riquelme.

Ahora, encontramos un limbo adolescente. Tenemos adolescentes sin exigencias que pueden jugar o vagar todo el día. Una madre asevera con relación a las expectativas de uno de sus hijos: "me conformo con que no sea un delincuente ni consuma pasta base". Así, estos nuevos pampinos, lejos de la reciedumbre del imaginario del pasado, no conocen de bototos ni overoles, visten tenidas deportivas, con camisetas de algunos de los equipos de las ligas de fútbol europeo, poleras con la imagen del Che Guevara o una con un impreso de Star Wars; otros insinúan un peinado punkie, con cabellos de tintes azules, rojos o verdes.

Ahora se puede ser adolescente y no conocer el trabajo. La ruptura se cristaliza con la retirada del "gringo". Nunca más la pampa vuelve a ser la misma, porque la mirada celadora del panóptico ya no está (Rodríguez 2004). Tampoco encontramos el viejo jardín edénico y utópico (Mege 2003 Ms); es la "comarca del olvido" (Miranda 2003 Ms). Por eso, los viejos pampinos se quejan de la juventud y observan como algunos de éstos destrozan el pueblo y les queda en la retina una riña, un asalto, los robos, la ebriedad, las drogas, el apedreo de los ventanales de la escuela, o, inclusive un asesinato.

Estos adolescentes no son necesariamente distintos a los que viven en cualquier ciudad del país. El 
impacto tecnológico no sólo viene dado por los grandes camiones mineros que trabajan en el "frente de explotación", sino por nuevos elementos simbólicos devenidos de las industrias culturales como la televisión, que inauguran una (nueva) adolescencia, es decir, una nueva posibilidad de ser, en una cultura que sólo conocía códigos uniformes. En el pasado, un niño era un trabajador pequeño; poco a poco se transformaba en uno más de la cultura salitrera, pues no había una transición entre la niñez y la adultez. No existía la adolescencia como fenómeno vital.

El gran tema de estos adolescentes, es el mismo que el de los viejos y de las mujeres: qué hacer con su tiempo libre. Ya no está lo que ofrecía la Oficina, cuando era un mundo cerrado. Es un mundo abierto, fundamentalmente por la televisión, los diarios y revistas, los trabajadores externos y las mejores vías de comunicación que permiten llegar con relativa facilidad a Tocopilla, Antofagasta, Calama e Iquique. Pero también, el gran tema de la empresa, como dueña de la infraestructura urbana, es qué hacer con los habitantes de este pueblo que debe ser subsidiado en términos de servicios básicos, y que además se hace cargo de personas no activas y no calificadas para el desempeño de sus actividades productivas.

Se ha empobrecido el mundo de la Oficina, pues ya no está el cine, el teatro, los talleres de pintura, el deporte, los bailes, las fiestas del salitre, las colonias veraniegas; y se ha enriquecido el mundo inaccesible que está fuera de ella. Pero no hay cómo salir. ${ }^{32}$ Por ejemplo, alrededor de 70 alumnos rindieron su Prueba de Aptitud Académica el año 2002, y sólo cinco tuvieron el puntaje necesario para postular a algún centro regional de educación superior.

La tensión entre el quedarse y salir de María Elena se diluye, pues, por "historia", objetivamente la formación académica no permite pensar en otro mundo como el que puede ofrecer la universidad, y en el caso de lograrlo, prácticamente no hay posibilidades de que los padres financien la educación superior.

La alternativa a esto es el overol rojo, el trabajo sin calificación. O el ocio.

32 Se nos señala: "es hasta difícil irse, porque el flete vale 500000 pesos".
Así, interrogados un grupo de adolescentes sobre lo que hicieron la noche anterior, responden: "Estuvimos hasta la una de la mañana en la plaza. Fumando".

Los ejemplos se pueden multiplicar. Al lado izquierdo de la entrada del Museo Municipal puede observarse la cristalización del horizonte de las expectativas. Durante tres años, y seis temporadas de trabajo de campo, cada tarde y cada noche, un grupo de adolescentes, principalmente varones, disfruta con un placer indescriptible los sabores de una cerveza, una caja de vino o una botella de pisco. De mano en mano, y de boca en boca, pasan las botellas que permiten hacer "más llevaderos" los días. Su mayor orgullo, son un par de sacos con los envases vacíos, los que se apilan con insigne complacencia y que cada semana son recogidos por el camión recolector de basura.

Para ellos, más allá de María Elena, nada. Dentro de María Elena, más de lo mismo.

¿Y qué sucede con los que se van?

"Hay algunos que se van y vuelven, porque no se acostumbran y adaptan por comodidad al sistema de vida de la ciudad. Le tienen pánico. Han vivido toda la vida aquí. Salieron de Victoria, se fueron a Vergara, y de Vergara a Pedro de Valdivia, y de Pedro a María Elena. Han recorrido toda la pampa salitrera y han viajado a la ciudad eventualmente, pero ahí sufren percances: les roban las credenciales de salud, la plata. Les roban porque aquí tienen una actitud distinta; salen de la casa y dejan la puerta abierta, tienden la ropa al aire libre...". ${ }^{33}$

No se adaptan, porque para ellos la ciudad tiene una estructura inmanejable, tienen que tomar locomoción de un lugar a otro, pagar. Lo trivial, lo cotidiano urbano, el desplazarse largas distancias dentro de la misma ciudad, es inquietante y perturbador. Tal vez, esto mismo es lo que hace, como hemos señalado en páginas anteriores, que se privilegien lugares pequeños para radicarse cuando el pueblo ya no exista o no les de oportunidad de seguir viviendo en él. Ahí, se reproduce el "lo conozco todo", "lo controlo todo". Esto impide el extravío.

33 Entrevista de historia oral realizada a Irma Soto, en María Elena, en enero de 2003 


\section{Epílogo}

Sabemos que la cultura representa unos límites de las posibilidades de ser, pensar e innovar. Pero, la modernidad asumida como uno de los ejes sustantivos en los que se ve reflejada la dinámica de una cultura, es sólo pensable bajo el principio de libertad, lo que instala como variable significativa la idea de autonomía del sujeto. Por ello, desde el punto de vista de la cultura se refleja una cuestión crucial: la ambivalencia entre creatividad y regulación (Bauman 2002: 22), pues no puede ser concebida sino es bajo la forma de la continuidad y la discontinuidad, como del enfrentamiento de la tradición con la novedad.

Por más obvio que parezca lo señalado, lo importante es observar-en perspectiva histórica- la profundidad que alcanza el proceso modernizador de la industria del salitre, pero en su conexión actual con el imaginario que le sustenta, ya que éste persiste y tiene una consistencia inequiparable con lo que se vive cotidianamente, pues las claves de la cultura se desvanecen y extinguen como lo hicieron innumerables chimeneas en el pasado. Ya no está la piara arrastrando las carretas, ni los chinos, los bolivianos y los niños-hombres; tampoco está la elegancia del gringo y su jardín botánico como recreación de algo de su historia desde el exilio; el sereno y su perro avisador ya no celan las fronteras de los barrios (Mege 2003 Ms; Rodríguez 2003 $\mathrm{Ms}$ ), es personal de Carabineros en furgones y motocicletas el que cautela el orden; tampoco están los Juan Bravo del relato de Martínez (1895), ni los trogloditas de Silva (1938), ni se encuentran los personajes de las novelas de Rivera Letelier, aún cuando el profesor Riquelme, crea, a propósito del impacto del libro La Reina Isabel cantaba rancheras, que la pampa nunca fue un lupanar -como fue allí descrita- y un testimonio en ese sentido es "difamación". ${ }^{34}$

Por lo mismo, razón tiene Candau cuando afirma que, "una vez que el lugar es producido, es difícil abolirlo" (2002: 112), y el imaginario del mundo salitrero sigue teniendo una fuerza que sobrepasa los límites de su propia configuración espacial, pues todos aquellos que van a la pampa anticipan la vida del salitre como una cuestión calamitosa e infausta. Lo cierto es que el camino tecnológico que va

\footnotetext{
34 Registro realizado en el invierno de 2001.
}

desde el sistema Shanks (de origen inglés) al Guggenheim (de origen norteamericano) es tan significativo y revolucionario como el paso de un sistema de caza y recolección a uno agrícola. Y es ello en gran medida lo que provocó el despoblamiento de la pampa y borró las huellas de mucho de lo que ha estado prendido en nuestras retinas, ya que la rudimentaria tecnología no conocida en las faenas en María Elena y Pedro de Valdivia, ni por los más antiguos habitantes que sobreviven en el último pueblo salitrero, tuvo insumos productivos de alto valor: la leña y el agua, y los animales y el forraje, en tanto, lo más barato fue la mano de obra (Rodríguez 2003 Ms).

Ahí está en gran medida la explicación del despoblamiento de la pampa. El vestigio material convertido en festín de traficantes y coleccionistas, sumado a las oscilaciones del precio del nitrato y la invención del salitre sintético la convirtieron en una empresa "no viable". Sin embargo, para los más viejos, lo cierto, cuando la explotación del salitre y sus derivados se convierte en un negocio monopólico y lucrativo, son los afectos los que afloran. Por una parte, como queja, se nos señala: "es mucho el daño que le hicieron al pobre..."; y, por otra, como esperanza: “... conserven esto para que las nuevas generaciones conozcan la historia de Chile", "porque después de Dios, creo yo, no hay nada mejor que María Elena".

El pasado es el único referente. Blanca Rosa sueña en lo social con asistir a un baile como "los de antes", con "ir al teatro", con "pasear por la plaza". Pero con cierta conformidad sus pretensiones se vuelven más modestas: quiere ir a tomar un shop con su amiga, "pero no hay donde ir". En lo doméstico, simplemente anhela "encontrar verdura fresca" como en el tiempo de los gringos. Blanca Rosa no puede preparar un "cocho", aún cuando vive de dar pensión, la única harina tostada encontrada en los almacenes del pueblo está agusanada. ${ }^{35}$

Nolberto Esquivel nunca escabulló el trabajo. De niño fue marcado por él. Fue vendedor de limones y naranjas, de paletas de agua, de pescados y mariscos, de pan; lustraba 10 o 12 pares de zapatos al gringo que lo mandaba a buscar con su chofer; recorría la plaza con su lustrín sacando brillo a los american shoes, fue repartidor de viandas, recolector

\footnotetext{
35 Registro realizado en el invierno de 2003.
} 
de latas y fierros, también acarreaba bultos a los pasajeros que llegaban en los buses, y más tarde, trabajó en los molinos de la compañía. Hay algo que Esquivel tiene claro: sus manos siempre han estado callosas, pero, también se ilumina con una esperanza, enguantárselas nuevamente, para ceñirlas sobre la cintura de una dama para así no romper su vestido, como fue tradición en todos los bailes obreros. ${ }^{36}$

El mundo del salitre popularizado hace más de una década por las obras de Hernán Rivera Letelier y las reediciones de "Hijo del Salitre" de Volodia Teitelboim y "Norte Grande" de Andrés Sabella, sigue siendo lugar de recuerdos, añoranzas e imaginación, aunque el territorio no ha encontrado un cartógrafo que pueda habérselas con el cambio que experimenta la cultura y -tal vez-con el fin de la misma, reflejado en María Elena, el último pueblo salitrero. Lo mismo ocurre con el peso que ha tenido, al menos en un par de generaciones, "La Cantata de Santa María de Iquique", ejecutada por el grupo Quilapayún, la que ha mantenido vivo uno de los hechos más tristes de la historia del movimiento social chileno.

Así, el arte también ha ayudado a conformar una especie de memoria colectiva, que posibilita que prácticamente todo el mundo pueda reconstruir imaginariamente el mundo de las salitreras, y que, pasada la sorpresa inicial de saber que aun existe en el país la industria del salitre, un último pueblo salitrero, y que unos hombres se hallan refugiado en él, se piense que ese mundo ha permanecido prácticamente igual, como un fósil social, como una suerte de pieza de museo en el cual se podrían encontrar los mismos elementos de los cuales hemos sabido por diversos autores que documentaron y recrearon este lugar.

Sin embargo, es un mundo que cambia, y hay un hecho puntual que de alguna manera parece actuar como metáfora de esta transformación que hemos enunciado de este "modo de ser" pampino: en las últimas elecciones presidenciales (1999), la candidata del Partido Comunista, representante de la izquierda más dura, obtuvo en la Comuna de
María Elena un 2.89\% de adhesión; en las municipales del 2000, el Partido Comunista "alcanza" un $0 \%$. En las elecciones presidenciales del mismo año, segunda vuelta, Ricardo Lagos obtiene un $57.57 \%$ de la votación, y Joaquín Lavín un $42.43 \%$.

Se desmitifica, entonces, la frase cien veces escuchada en todas nuestras conversaciones en el trabajo de campo: "el pampino siempre ha sido de izquierda".

¿Es esta "derechización" de la pampa un componente evidente por lo atípico de un cambio de la cultura pampina? ¿un anuncio de su desaparición? ¿podemos hablar de una "nueva cultura pampina? ¿de un pampino postmoderno? ¿qué hechos marcan su nacimiento? ¿cuáles son sus características, sus referentes? ¿cómo se percibe a sí mismo? ¿qué lo vincula al pasado de la pampa? ¿en qué se reconoce? ¿tienen pasado en la pampa? ¿son los nuevos pioneros de una actividad moribunda desde los años 30 y que hoy se ha convertido en un negocio lucrativo y sin competidores en el mercado mundial?

Son estas preguntas y muchas más las que abren nuevas rutas de investigación social, especialmente a la etnografía dedicada a ver lo que otros no ven y a oír los procesos de construcción de las subjetividades de los actores en diálogo y relación con las estructuras sociales pasadas y presentes, y a la fundación de distintos locus desde donde se habla y construye la esperanza del día a día. También, a la antropología, que las más de las veces, atrapada en la nostalgia, quiere conservar cierta pureza prístina, más que asumir la inevitabilidad del cambio de una tradición como la del mundo del salitre, esta vez, encarnada en los eleninos.

Agradecimientos A los habitantes de María Elena, que al abrir sus vidas y compartir sus esperanzas han permitido el desarrollo de esta investigación. Al Sr. Jorge Araya, Jefe de Campamento en María Elena, por su hospitalidad, al director del museo de María Elena Eduardo Ramos amigo y consejero, y muy especialmente al profesor Riquelme por su sabiduría y generosidad.

36 Registro realizado en el invierno de 2001. 


\section{REFERENCIAS CITADAS}

ALVARADO, M., 2002. La imagen de lo no vivido. Memoria y fotografía de las salitreras del norte de Chile. Aisthesis, Revista Chilena de Investigaciones Estéticas 35: 41-49.

BAHAMONDE, M., 1945. Pampa volcada. Ediciones Cultura, Santiago.

—1951. De cuán lejos viene el viento. Ediciones Grupo Letras, Antofagasta.

BAUDRILLARD, J., 1993. Cultura y simulacro. Kairós, Barcelona.

BOUDAT, L., 1889 [2001]. Salitreras de Tarapacá, Iquique. Segunda edición facsimilar, Biblioteca Nacional, Santiago.

BAUMAN, Z., 2002. La cultura como praxis. Editorial Paidós, Barcelona.

CANDAU, J., 2002. Antropología de la memoria. Ediciones Nueva Visión, Buenos Aires.

COBO, J., 1971. Yo vi nacer y morir los pueblos salitreros. Editorial Quimantú, Santiago.

GARCES, E., 1999. Las ciudades del salitre. Editorial Orígenes, Santiago.

GONZALEZ, S., 2002. Hombres y mujeres de la pampa. Tarapacá en el ciclo del salitre. LOM Ediciones, Santiago.

GONZALEZ CENTENO, L., 1954. Caliche. Editorial Nascimento, Santiago.

1956. Los pampinos. Prensa Latinoamericana, Santiago.

HOBSBAWN, E. y T. RANGER, 1983. The invention of tradition. Cambridge University Press, Cambridge.

LEHNERT, R., 1997. Diccionario de léxico salitrero. Universidad de Antofagasta, Antofagasta.

MARTINEZ, M., 1895. Historia de un esclavo. Imprenta el Jornal, Iquique.

MEGE, P., 2003 Ms. La utopía Guggenheim. Los paraísos evocados en la Oficina Salitrera María Elena. Ponencia presentada en el $51^{\circ}$ Congreso Internacional de Americanistas, Santiago.

MIRANDA, P., 2003 Ms. La comarca del olvido. Ponencia presentada en el $51^{\circ}$ Congreso Internacional de Americanistas, Santiago.

NERUDA, P., 1967a. Los hombres del nitrato. En Canto General. Obras Completas, T I: 501-502. Editorial Losada, Buenos Aires.

1967b. Saludo al norte. En Canto General. Obras Completas, T II: 1059. Editorial Losada, Buenos Aires.
RECABARREN, J., 2002. Episodios de la vida regional. Ediciones Universidad Católica del Norte, Antofagasta.

2003. La matanza de San Gregorio. 1921: Crisis y tragedia. LOM Ediciones, Santiago.

RIVERA LETELIER, H., 2002. Santa María de las flores negras. Seix Barral, Buenos Aires.

RODRIGUEZ, J., 2001. La mala memoria y la muerte feliz en María Elena, un pueblo salitrero en el Desierto de Atacama, Chile. Revista Antropológicas 18: 67-75.

_ 2003 Ms. Duelo y sentido de lo trágico en la tierra del nitrato. Los últimos trabajadores del salitre buscando un lugar. Ponencia presentada en el $51^{\circ}$ Congreso Internacional de Americanistas, Santiago.

2004. La reinvención del paraíso: Sueño y olvido en los habitantes de los últimos pueblos salitreros del Desierto de Atacama, Chile. En Desierto y fronteras. El norte de México y otros contextos culturales. V Coloquio Paul Kirchhoff, H. Salas y R. Pérez (Eds.), pp. 123-152. Universidad Nacional Autónoma de México - Instituto de Investigaciones Antropológicas, Plaza y Valdés, México D. F.

RODRIGUEZ, J., P. MIRANDA y P. MEGE, 2002. Etnografía de la Siberia Caliente. Una nota metodológica sobre un estudio en María Elena, el último pueblo salitrero. Estudios Atacameños 22: 105-125.

REYES, S., 1963. Andanzas por el Desierto de Atacama. Editorial La Portada, Antofagasta.

SABELLA, A., 1997. Norte Grande. LOM Ediciones, Santiago.

SHILS, E., 1981. Tradition. Faber \& Faber, Londres.

SILVA, D., 1938. La Pampa trágica. Editorial Zig-Zag, Santiago.

TEITELBOIM, V., 1996. Hijo del salitre. LOM Ediciones, Santiago.

TODOROV, T., 2000. Los abusos de la memoria. Editorial Paidós, Barcelona.

\section{Revistas}

Revista Pampa, Editorial Zig-Zag, Santiago, nº 9, diciembre de 1948; ${ }^{\circ} 12$, marzo de $1949 ; n^{\circ} 65$, agosto de 1953.

Revista Norte Minero, Antofagasta, Año V, ${ }^{\circ}$ 63, agosto de 2002.

Revista Mundo SQM, Fontaine Editores, Santiago, $\mathrm{n}^{\circ}$ 8, abrilmayo-junio de 2003. 
